Meta

Journal des tradlucteurs

Translators' Journal

\title{
Reviewing a Translation: A Practical Problem in Literary Criticism
}

\section{Félix J. Douma}

Volume 17, numéro 2, juin 1972

URI : https://id.erudit.org/iderudit/002582ar

DOI : https://doi.org/10.7202/002582ar

Aller au sommaire du numéro

Éditeur(s)

Les Presses de l'Université de Montréal

ISSN

0026-0452 (imprimé)

1492-1421 (numérique)

Découvrir la revue

Citer cet article

Douma, F. J. (1972). Reviewing a Translation: A Practical Problem in Literary

Criticism. Meta, 17(2), 94-101. https://doi.org/10.7202/002582ar d'utilisation que vous pouvez consulter en ligne.

https://apropos.erudit.org/fr/usagers/politique-dutilisation/ 


\section{Reviewing a Translation A Practical Problem in Literary Criticism}

Handing out advice is at best a tickiish proposition, especialiy when the intended recipient (in this case a literary critic who is about to write a review of a translation) has expressed no need for it. Accordingly, although I have taken it upon myself to offer some anyway, straight pieces of advice have been kept to a minimum in this account. I would rather see it as an introduction to the problems which one is likely to encounter in writing a review of a translation.

Suppose that $I$ have been given the opportunity to review the translation of a literary work which falls within my range of expertise. What I will say about it may be seen as largely determined by the fact that what $\mathbf{I}$ am reviewing is, after all, a book. There are many sorts of information which regularly appear about a book in a review. Along with commentary more closely concerned with the author's performance, there is often discussion of the book's place in the literature of its kind or period, the influences which have left their mark upon it, the peculiarities which set it apart, and so on. An ordinary book review also quite often contains remarks about the author, and other books he may have written. Finally, such a review may contain information about the edition - index, apparatus, print, paper, binding, and errata.

This outline of what one may expect to find in a book review is not complete ; but it could very well be used as a list of check-points for an adequate review of an ordinary book. The point I wish to make here is that, when the subject of a review is a translation, the possibility, perhaps even the necessity of an entirely new dimension of commentary is opened up - namely, commentary on the performance of the translator of the work. This dimension of commentary over and above the kinds of remarks usually found in book reviews is the preoccupation of this paper. I do not mean to suggest, of course, that commentary of the sort usually found in book reviews has no proper place in the review of a translation. The most that I may eventually be able to assert in this line is that commentary of the book review kind constitutes only a part of the requisites for a good translation review. 
But what will in all likelihood be considered a good translation review depends on a number of circumstances attending its appearance. Among these is the nature of the publication in which it is to be printed, and the kind of readers who may be expected to draw benefit from my critical services. These are homely considerations of an editorial kind, but nevertheless of great relevance to the journalistic function of literary criticism, to which the writing of reviews surely belongs. A quite suitable review of Goethe's Faust published in the Star Weekly Supplement will not always do for more academically-oriented publications and vice versa. But it seems fairly clear that the editorial issues on which the reviewer must make decisions stem from contingencies whose variety would be difficult if not impossible to schematize here. For the sake of the argument, let us assume that my review is to be published in a sound, scholarly journal of international reputation, whose readers constitute the most well-informed and intelligent public that any critic might wish for - in other words, that I may safely soft-pedal limitations of the editorial kind.

This assumption, although it is helpful to this discussion in the sense that it puts my «professional » business in sharper focus, does not rid me of another arbitrary determining factor, namely a limitation of space. For reasons which will become clear shortly, let us assume that I have been allotted the space of two or three printed pages for the review - just a bit more than the standard book review in (say) the Times Literary Supplement.

The problem with which I started out may now be reformulated as follows : in what way shall I fill up my two or three printed pages so as to provide the best possible critical service? As an aid to reflection on this topic, one might try to guess in what way members of the public will depend on this service. There may be students in a modern language programme looking for a «crib» or « pony ». There may be lecturers in comparative literature programmes wondering whether to recommend the translation on next year's « suggested further reading 》list, or indeed wondering whether to read it themselves. Obviously, there are a lot of things which one might usefully tell them. Some of these things will undoubtedly turn out to be remarks of the kind one may expect to find in an ordinary book review ; but given our assumptions at this point, it is also quite clear that a major and indispensible part of my business as critic is to pass an informative judgment on the performance of the translator. It would be difficult to exaggerate the importance of my function as a critic in situations like this. Those who are looking for a well-founded judgment of a translation's value are often not in the position to make this judgment for themselves because they do not read the language of the original well enough. Perhaps they do not read it at all.

The problems involved in passing such a judgment are considerable, but not insurmountable. It need, for example, not be a judgment that the translation is either good or bad - indeed, such a judgment unaccompanied by fairly detailed considerations leading up to it will be of little interest to the public. In practice, judgments about the worth of a translation are contained in more subtle terminology. Translations are, for example, called accurate, careless, clear, clumsy, consistent, correct, dull, free, graceful, imprecise, inconsistent, incorrect, insensitive, learned, literal, loose, pedantic, precise, sensitive, stilted, suitable, unsuitable, 
vivid, wordy, and so on. The public will be profoundly interested to consider whatever arguments or examples I may be able to produce in order to show that a selection of the above or other epithets apply to the translation under review. Within my two to three-page limit, I may in addition very well find space to comment on the translator's handling of a number of standard translation difficulties such as the translation of personal and place names, the translation of archaic and other culture-bound words and expressions, and (especially in the case of poetry) to what extent the translator was able to do something with the sound patterns and rhythms of the original. A very handy way of organizing the discussion of a number of these points is to run a comparison of the translation under review with a previous translation of the same original by someone else (if this is available). Simply quoting a few lines from each version may speak volumes. Finally, in their introductions to the translations, translators themselves often say what they consider to be the strong and weak points of their work, thus providing the critic with an obvious point of entry.

On the face of it, there would seem to be little to stop the conscientious critic from producing an informative and fair review of a translation. It is true that he will not be able to discuss all of it : he will not be able to cover every item which has been vividly or clumsily translated. But no one expects this of him. What the public may reasonably expect, however, is that the critic, speaking from a position of familiarity with both the original and the translation, and aware of the literary context within which the translation was written, will offer a well-founded judgment of the translator's performance. If it is a mixed performance (as it often turns out to be), the critic is expected to say so, to specify a few constituents of the mixture, and (possibly) to offer a judgment on whether or not it is ore of a high grade.

The assumptions made in the course of this discussion would seem to justify suggesting a prescription for the relative importance which should be accorded to information of the book-review kind and discussion of the translator's performance respectively. Here it is : in general, book review commentary ought to be kept to a minimum. Students looking for a «crib» and lecturers looking for an addition to the «suggested further reading 》 list will not need to be told that Goethe was an important German poet. Exceptions to this rule, of course, are conceivable. In the case of translations of obscure books from little-known literatures, for example, the ordinary book-review kind of commentary may very well be of use or interest to the public.

The foregoing introduction to the problem of how to set about reviewing a translation is fairly straight-forward and may appear simple-minded. The reader of this account may very well ask why the matter should have been laboured so. The answer is that the job of reviewing a translation is very often badly done. A great number of translation reviews which have appeared in North America in the last twenty years are unhelpful to anyone. A substantial proportion of these contain both irrelevant information and unfair criticism of the translator's performance. Before lending support to this contention by proffering some exhibits, it may be useful to sketch briefly how translation reviews usually go wrong. 
Translation reviews which have appeared in North America recently are subject to two main kinds of error. The first of these is an error of emphasis. It occurs in most cases where the reviewer writes at length about the original, but offers no commentary on the way in which it has been translated. It must be kept in mind that a good proportion of English literary translations appearing nowadays are "classics》 from other literatures. Reviews which suffer from what I have called an error of emphasis offer the reader little or no help in deciding which of the perhaps many available translations they should read if they cannot take the time to read all of them. But this first kind of error remains a fault of emphasis, and is as such impossible to eliminate by applying hard and fast rules.

The second main kind of error to be found in translation reviews flows out of a fundamental wrongheadedness, and is by far the more serious of the two, since it not only misrepresents the translator's profession, but also leads inevitably to an expressed or implied detraction of their work. The error as it may be uncovered in individual reviews takes many shapes and is often obscured by qualifications; but it usually appears as a variation on the following general theme : 1) we have here a translation of a literary work ;2) satisfactory translations of literary works are impossible ; 3) therefore this translation is unsatisfactory.

It is commonly believed that literary works are in some sense untranslatable. To go into this question, or to attempt to specify precisely in what sense this may be so is outside the scope of this paper. The important point is that such a contention can have no bearing on the evaluation of a translator's performance. Favourable or adverse criticism of a translation makes sense (is fair) only if the translator could have done otherwise with the means at his disposal ${ }^{1}$.

My exhibits have been gathered from the translation review section of the Yearbook of Comparative and General Literature, which has been published annually since 1952 in collaboration with the Comparative Literature Committee of the National Council of Teachers of English (U.S. A.), the American Comparative Literature Association, and the Comparative Literature Section of the Modern Language Association of America. It is a sound, scholarly journal of international reputation, whose readers may be said to constitute the most wellinformed and intelligent audience a critic might wish for. It is not entirely by chance that the physical proportions of the translation reviews in the Yearbook also correspond closely with the previously-given hypothetical figure of two or three printed pages. Some one hundred and fifty translation reviews were published in the Yearbook from the first year of its issue up to and including its 1967 number. Nearly half of these reviews suffer from misplaced emphasis as explained above. A substantial proportion contains some version of the wrongheadedness which I characterized as the second main type of error to which translation reviews are subject. Aside from this, the reviews contain an amazing variety of irrelevant

1. Consider the following analogy : I am an expert on medieval castles, and have been called in to offer my views on the reconstruction of a twelfth century German castle which has been moved, brick by brick, to the estate of a multimillionaire in Texas. To say without specifying further that the whole thing is awful, or that it does not make the same impression as it did in Germany is unfair criticism of the contractor in charge of the work. If I were to point out that the doors in the dining-hall had been installed upside-down, that would be fair enough, if true. 
commentary and information ${ }^{2}$. I have no reason to suppose that the over-all quality of the translation reviews in the Yearbook is below that to be found in other sources - on the contrary, the Yearbook's transiation reviews are surely, generally speaking, among the best one is likely to find anywhere in North America. It is worth noting too that these failings are not the result of editorial prescription. An inquiry to the editors of the Yearbook has confirmed that the reviewers were left entirely on their own in determining the drift of their commentary.

As I said before, it is impossible to give hard and fast rules to prevent the occurrence of errors of emphasis. However, one would seem to be on fairly solid ground in suggesting that a translation review of a «classic » from another literature ought to contain at least some commentary on how the translation has been executed. Several reviews in the Yearbook entirely lack such commentary. Examples are Kenneth Ward Hooker's review of G. D. H. Cole's translation of Rousseau's The Social Contract and Other Discourses (vol. I, p. 72-73), and Victor Lange's review of Willa and Edwin Muir's translations of selected stories by Franz Kafka (vol. III, p. 97-99). Of course, these are extreme cases. Far more numerous are examples of the scarcely less objectionable practice of passing off-hand commentary (usually faint praise), in one or two sentences ${ }^{3}$.

The wrongheadedness which I characterized as the second main fault of translation reviews also appears in the first issue of the Yearbook, and wanders variously disguised through succeeding numbers. As I suggested before, it has its origins in the relief that every translation is unsatisfactory in some sense, and consists in imputing this unsatisfactoriness to a failure on the part of the translator. Even if no translation appears to have been rejected outright on these grounds alone, this belief seems to have led in many cases to qualified judgments of their worth.

«The best of Cervantes is untranslatable », quotes John M. Hill in a review of M. J. Cohen's translation of The Adventures of Don Quixote. He then goes on to suggest that on these general grounds, scholars and people familiar with Spanish will probably not approve of Cohen's version. Nevertheless, Mr. Hill recommends it «with entire confidence» for the general reader, after having pretty well abdicated from his function as critic by saying : "How well has Mr. Cohen succeeded in his task? The answer will depend, very naturally, on the individual reader's point of view $\gg$ (vol. I, p. 69-70).

The translator's « ... work, by its very nature, is doomed to fall short of the original », writes Foster W. Blaisdell Jr. (vol. VI, p. 83-84). In other reviews, this point is couched in other terms : translations "do violence 》 on the original; the bed of Procrustes is rolled out, and so on ${ }^{4}$. The rather sombre judgment implied by this point of view on the subject of translation as a profession has not

2. This came to light in the course of James S. Holmes' 1969-1970 Research Seminar in the Translations Studies Programme of the Department of Literary Studies at the University of Amsterdam. Both Mr. J. S. Holmes and Prof. F. Sparshott (Toronto) offered helpful comments on an earlier version of this paper.

3. For example, Harry Steinhauer (vol. I, p. 79-80); R. L. Predmore (vol. XI, p. 44-46) ; Robert A. van Kluyve (vol. XIII, p. 71-72) ; and Kemp Malone (vol. XIII, p. 70-71).

4. For example, Christopher Thacker (vol. XV, p. 74-75); Arthur Burkhard (vol. VII, p. 89-93) ; Philip Walker (vol. XII, p. 88-89). 
gone unnoticed. "The translator's lot, writes Karl S. Weimar, ... is not a happy one » (vol. XI, p. 47-48).

Vernon Hall Jr., in a review of two translations of Dante's Divine Comedy, offers the following observations :

Since all agree that poetry is untranslatable and the greater the poet the more annoying the attempt, the tendency is to dismiss all translations of the Divine Comedy as bad. It would be nearer the truth to say, with the obvious reservations in mind, that most of the translations of this greatest of long poems are good. No one untouched by the beauty of the original, no one not dedicated to the genius of Dante, could possibly undertake the immense labor of making an English version (vol. XI, p. 43-44).

Apparently Mr. Hall realized that there must be something wrong with a line of reasoning which would be sheer definition consign so much painstaking work to the limbo of near misses. Unfortunately, the alternative account which he suggests is nearer to the truth seems no less erroneous. No matter how dedicated or touched the translator may have been when he set out to translate, it remains to be seen what kind of a translation he has produced.

For my last few exhibits, I have chosen a variety of pieces of irrelevant information contained in translation reviews. My broad criterion of the relevance of any bit of information found in a review was that of its possible helpfulness to the public. Of course, a wide variety of things could be more or less relevant. I have been assuming that the reader of a translation review will find a wellreasoned judgment of the translator's performance helpful. However, he may also be interested in seeing evidence to support the view that the translation under review was largely or completely plagiarized from a previous translation, or that the translation was not made from the original text, but from a translation in a third language ${ }^{5}$. In my opinion, the introduction of ethical issues into translation reviews, no doubt sometimes defensible on ethical grounds, tends in general to obscure the more obvious business at hand, and to the extent that it takes up room which might have been used for a more «professional » appraisal of the translation, renders the review less helpful to its readers. But it is a difficult point, and not one to which I am prepared to offer the ultimate solution here. In any case, it will not do to ascribe ethical qualities to the translations themselves, as Robert L. Jackson does when he imputes a «charlatan character» to a newlyrevised edition of the H. Sutherland Edwards translation of The House of the Dead by Dostoyevsky. Mr. Jackson's ethical objection was that he believed that the revision was made without any reference to the Russian text (vol. XIII, p. 75-76). It is perhaps worth spelling out here that even as the very best intentions on the part of the translator do not guarantee that the translation will be any good, the most shabby commercialistic motives on the part of the translator, the publisher, or both, do not necessarily mean that the translation as such will be bad. Disapproval of a translation as such should always be kept distinct from a call to boycott it on ethical grounds.

In this connection, consider the following comments by P. M. Mitchell in a review of Prof. Ellis-Fermor's translations of three plays by Hendrik Ibsen :

5. See, for example, Lander MacClintock (vol. X, p. 85-86), and Robert A. Charles (vol. X, p. 78-82). 
The new translations of Ibsen are accurate and acceptable - but were they necessary? Was the expenditure of time and effort to produce them justifiable ? I am inclined to think that Mme Ellis-Fermor would perform a greater service to literature, and therewith save herself many valuable hours, by revising Archer's translations of the prose plays... (vol. I, p. 77-79).

The issue which Mr. Mitchell raises here seems less urgent than the ethical questions surrounding a translation's provenance mentioned above, but it remains an issue in a similar vein - namely that of whether or not the translator ought to have undertaken to do the translations in the first place. It is obvious in this case that the issue is irrelevant. Mr. Mitchell's implied judgment (i.e that Prof. Ellis-Fermor should have spent her time doing something else) is hardly of interest to anyone except (possibly) Prof. Ellis-Fermor. The judgment, offered to her through this channel, is not only indefensible on ethical grounds, but indeed profoundly meddlesome.

My last exhibit in this series is taken from Arthur Burkhard's review of E. H. Zeydel's English translations of one hundred poems by Goethe. In the course of the review, Mr. Burkhard writes :

... Moritz Haupt advised : "Never translate, translation is the death of all understanding. » Doctor Johnson quotes : «Nor ought a genius less than his that writ attempt translation. $\gg$ Robert Bridges, after inspecting a version of Dante in English, cried incredulously : "Can anything be more like broken crockery? 》 Cervantes felt translations resembled the wrong side of a tapestry : the figures are visible but full of threads that obscure the view. A pun more readily comprehensible in Britain than here points out : "Nothing improves by translation except a bishop», and an old familiar couplet denigrates all who would indulge themselves in such futile pursuits : «When lo! Translation comes and levels all,

By vulgar hands the bravest heroes fall. »

Wilhelm von Humboldt did not hesitate to point out to August Wilhelm Schlegel : «Alles Übersetzen scheint mir schlechterdings ein Versuch zur Auflosung einer unmöglichen Aufgabe. » Julius Keller bluntly asserts : «Das wirklich Übersetzbare ist nichts weiter als der gerupfte Vogel. » Perhaps after all Dante, followed much later by Benedetto Croce, was correct in maintaining that all translation of good poetry is impossible. We can only humbly hope that the guiding principle of this art of translation should be faithfulness to the author, the stylistic aim perfect naturalness of expression : « Better a live sparrow than a stuffed eagle. $\gg . .$. Goethe himself held that the translator is a person who introduces you to a veiled beauty; he makes you long for the loveliness behind the veil (vol. V, p. 81-93).

It is surprising how often one finds quotations or general remarks of this kind in translation reviews. Their appearance time after time suggests that we have here to do with a ceremonial gesture - a kind of grace before dinner, or last cigarette. It is, I suppose, possible to see them as embellishments to the review, serving as a general orientation to the discussion at hand. But it is difficult to imagine how the results of a forage in Bartlett's Quotations or similar source might help to inform the public about the translation(s) under review. For this reason, I tend to deplore their presence.

It would hardly be fair to past and present editors of the Yearbook and the many scholars who have contributed to the content of its translation review section to close this exhibition without making explicit mention of the fact that 
I have been able to refer to only a small selection of the reviews which have appeared in it since 1952. Quite naturally, I have selected those reviews which illustrated most clearly the points I wished to make. It is true that the faults which have been illustrated here are disturbingly wide-spread. But on the other hand, I also found a number of good, informative translation reviews ${ }^{6}$.

Finally, a few words on why the whole issue of how and how not to write translation reviews seemed to be worth going into the stacks for. An eighteenyear-old review is a very old review indeed, and there is generally a lot to be said for the practical wisdom of letting bygones be bygones. But the record shows that certain objectionable features of translation reviews have persisted through the years. Offering a few suggestions on how to perform this vital job in literary criticism may serve to introduce it to those who are new to its problems. The public may ultimately be able to read more helpful reviews. In addition, there is a translator's axe to grind. The appearance of more hard-headed translation reviews may in time even help to explode the current image of the translator as a hopeless moth on a lightbulb.

FÉLIX J. Douma

6. Examples are reviews by D. M. Frame (vol. I, p. 70-72) ; Edward B. Irving (vol. XV, p. 66-70) ; Leland H. Chambers (vol. XVI, p. 79-84). 